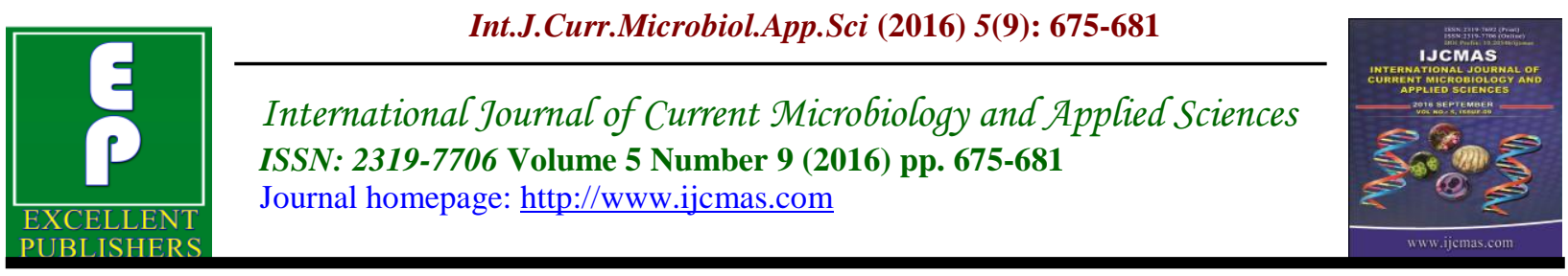

Original Research Article

http://dx.doi.org/10.20546/ijcmas.2016.509.078

\title{
Bioconversion of Water Hyacinth into Enriched Vermicompost and its Effect on Growth and Yield of Peanut
}

\author{
S. Sridevi ${ }^{1}$, M. Prabu ${ }^{2 *}$ and N.G. Tamilselvi ${ }^{1}$ \\ ${ }^{1}$ Department of Zoology, Annamalai University, Chidambaram - 608002 Tamil Nadu, India \\ ${ }^{2}$ Department of Biology, Gandhigram Rural Institute, Gandhigram - 624302 Tamil Nadu, India \\ *Corresponding author
}

\begin{abstract}
A B S T R A C T
Keywords

Water Hyacinth,

Earthworm,

Vermicompost,

Peanut,

Organic Manure.

Article Info

Accepted:

25 August 2016

Available Online:

10 September 2016

Water hyacinth (Eichornia crassipes [Mart.] Solms) is alien invasive hydrophytes that cause environmental hazardous. Bioconversions of water hyacinth through vermicomposting were attempted. In the present study water hyacinth integrated with cow dung (1:3) was allowed for composting for a period of 45 days by using earthworm species Eisenia foetida. Later it was subjected to analysis of microbial flora (Bacteria: $93.07 \times 10^{-6} \mathrm{CFU} \mathrm{g}^{-1}$; Fungi: $118 \times 10^{-2} \mathrm{CFU} \mathrm{g}{ }^{-1}$ and Actinomycetes: $77.52 \times 10^{-3} \mathrm{CFU} \mathrm{g}^{-1}$ ), physicochemical characteristics, nutrients (Nitrogen $2.85 \%$, Phosphorus $2.10 \%$ and Potassium $3.05 \%$ ) and employed as good organic manure for the pot culture of the leguminous crop namely Peanut (Arachis hypogaea L.) and was found to be a better growth and yield.
\end{abstract}

\section{Introduction}

Vermicomposting is a biotechnological process that transforms energy rich and complex organic substances into stabilized humus-like product known as vermicompost. It improves soil structure, aeration and increasing water holding capacity. Earthworm as a potential biological tool should be much better understand to make organic farming and sustainable development with the use of selected species of earthworms (Kale, 1998). Earthworms were specialized to live in decaying matter and can degrade it into fine particulate materials were high in available nutrients with considerable potential and soil activities (Edwards, 1998).
Origin of water hyacinth is South America and Venezuela in particular. Water hyacinth polluted water bodies that would be converted from palatable to unpalatable by producing a fowling smell. Mostly the water hyacinths grow very well in sewage water. The normal water bodies such as ponds, lakes, and canals are contaminated with sewage water. This was the indicator either the water was contaminated or not. Nowadays the controlling of this aquatic weed was a major problem but through the vermitechnology, this problem was easily solved. The other effect of the fast growth of these weeds affects the physical interference with fishing obstruction of shipping routes 
and losses of water in irrigation systems due to higher evaporation and interference with hydroelectric schemes and increased sedimentation by trapping silt particles. It also restricts the possibilities of fishing from the shore and causes hygienic problems (Abdelhamid and Garber, 1991). In addition, it was threatened the livelihood of communities by reducing fish population and providing habitats for malaria by contaminating water due to decomposition and loss of water through the high rate of evaporation. Since water hyacinth has lot of disadvantages. It possesses some potential values like making composting and mulching (Gajalakshmi et al., 2001). The present study was focused on composting of the water hyacinth and evaluation of compost as organic manure for the cultivation of an oil crop Peanut (Arachis hypogaea L.).

\section{Materials and Methods}

The water hyacinths (Eichhornia crasipes) were collected from in and around the Annamalai University Campus, Chidambaram, Cuddalore (TN). The earthworm species Eisenia foetida were collected from mass culture tank, Department of Agriculture, Annamalai University.

The water hyacinths were cut into $1-2 \mathrm{~cm}$ small pieces and allow it for sundried up to half its fresh weight, in order to facilitate decomposition process. The wastes were kept either in a tank or plastic trough. The tank was covered with gunny bags and sprinkling water with regular turning for every 20 days. One week old cow dung was used in an experiment because fresh cow dung can be dangerous for earthworms due to decomposition process when the generation of heat take place that can kill to earthworms. To preparing the vermin bed the predecomposed water hyacinth was weighed and mixed with dried cow dung in $1: 3(\mathrm{WH}+\mathrm{CW})$ ratio in plastic troughs of $45 \times 35 \times 15 \mathrm{~cm}$. The substrates were moisture to hold 70 to 80 percent of moisture content by the sprinkling of adequate quantities of water at regular interval and kept for 24 hours stabilization. Five hundred healthy clitellate Eisenia foetida were introduced in a plastic trough. The vermicomposting processes were carried out in the rearing room. The substrates were turned once in a week and maintained up to 45 days. The experiment was done by using proper control and triplicates. The vermicompost was analyzed for various physicochemical parameters such as $\mathrm{pH}, \mathrm{EC}, \mathrm{N}, \mathrm{P}, \mathrm{K}$, and $\mathrm{C}: \mathrm{N}$ ratio.

The microbial population was determined by using serial dilution technique using colony forming unit (CFU). The phosphate solubilizer (Pseudomonas spp.) and nitrogen fixer (Rhizobium spp.) were identified and mass culture. These microbial fertilizers were added $2.5 \mathrm{ml}$ with 45 days old vermicompost at a load of $10^{-8}$ cells per gram. The Peanut was allowed to germinate and allowed to grown in pot culture study using soil mixed with enriched vermicompost at 1:1 $\left(\mathrm{T}_{2}\right) ; 1: 2\left(\mathrm{~T}_{3}\right) ; 1: 3\left(\mathrm{~T}_{4}\right)$ and 1:4 $\left(\mathrm{T}_{5}\right)$ ratio. The experiment was conducted in triplicate and a control (soil alone $\mathrm{T}_{1}$ ). Growth and yield parameters such as plant height, root length, number of leaves, shoot and root biomass, number of root nodules, number of individual fruits and its weight were observed and recorded in 30, 60, and 90 days intervals.

\section{Statistical Analysis}

Experimental data were expressed as mean \pm S.E of triplicates and all these data's were analyzed using SPSS statistical package. Significant difference $\mathrm{P}>0.05$ and 0.01 
between control and treatments were determined by student's t-test. The data were analyzed statistically by balanced ANOVA and one-way classification at one per cent level using Minitab 15.

\section{Result and Discussion}

Physico-chemical characteristics of the compost were analyzed and the recorded values are given in Table: 1 . The $\mathrm{pH}$ of the vermicompost was increased an initial stage of composting ( $\mathrm{pH}$ 8.54) and it was decreased final stage of composting $(\mathrm{pH}$ 7.45). The $\mathrm{pH}$ was maintained neutrally during the vermicomposting process because the organic acid was neutralized and also the nitrifying bacteria lowered the $\mathrm{pH}$ due to the nitrification process. From this process liberation of hydrogen ions, however, once nitrification had begun after the thermophilic stage $\mathrm{pH}$ was decreased and $\mathrm{pH}$ value of the compost were directly related to nitrification (Sanchez - Monedero et al., 2001). The Electrical Conductivity of the vermicompost was high in initial stage and it was reduced in final phase of composting because the volatilization ammonia and the precipitation of mineral salt could be the possible reasons for the decrease of EC. The EC value reflected the degree of salinity in the Vermicompost indicating its phytotoxicity / photoinhibition effects on the growth of plant if it was applied to the soil (Huang, 2004). The result shows that required EC value was observed in composted of water hyacinth.

The total nitrogen was higher $(2.85 \%)$ in final stage of vermicomposting than an initial stage $(1.77 \%)$ over the control. The total nitrogen was increased due to the recycling of nitrogen in process it shows that the good quality of vermicompost. The addition of nitrogenous metabolic products of earthworms also leads to increase the nitrogen concentrations which were return to the soil through casts and mucoproteins. The nitrogen availability was more during vermicomposting (Bhattacharya and Challopathyay, 2004). The total phosphorus was increased from initial $(0.93 \%)$ to final $(2.10 \%)$ over the control $(0.80 \%$ to 0.87 $\%)$. The increase of total phosphorous content revealed that the vermicomposting process is in order. Normally the phosphorous was found in available forms like calcium phosphate or potassium phosphate. This study reveals that worms have the ability to convert insoluble phosphorus into soluble form attributed by phosphate solubilizing microbes present in the earthworm cast. Vermicompost was proved to be an efficient technology for providing better phosphorous nutrition from organic waste which is in accordance with Ghosh et al. (1999).

The total potassium was slightly decreased from initial $(1.51 \%)$ stage and increased $(3.05 \%)$ in the final stage of vermicompost of water hyacinth over the control. The mineralization of potassium was more in vermicompost of water hyacinth which indicates the role of earthworm and microbes in mineralization process (Suthar, 2007) induces higher total potassium content at the degradation of water hyacinth by Eisenia foetida (Gupta and Garg, 2003). Potassium was a nutrient that plays a role in many physiological processes and also essential for plant growth including the maintenance of plant water balance and protein synthesis. From the data mineralization of NPK was observed high in worm worked compost of water hyacinth over than the control. The present investigation was supported by few findings of Ananthakrishnasamy et al. (2007) which had reported increased NPK content in the vermicompost than the original feed material. 
According to Kale (1998) vermicompost has following status of nutrients, organic carbon $9.15 \%$ to $17.98 \%$, total nitrogen $0.5 \%$ to $1.5 \%$, available phosphorus 0.1 to $1.0 \%$, available potassium $0.15 \%$ to $0 \%$, calcium and magnesium $22.67 \%$ to $47.60 \mathrm{Mec} / 100$ $\mathrm{mg}$, copper 2.0 to $9.5 \mathrm{ppm}$, iron 2.0 to 9.5 ppm, zinc 5.7 to $11.5 \mathrm{ppm}$, sulphur 128.0 to $548.0 \mathrm{ppm}$. The result shows organic carbon was reduced from initial into final over the control. The reduction of organic carbon is due to the respiratory activity of earthworm and microbes (Curry et al., 1995). This reduction was partially due to microbial degradation of organic carbon into $\mathrm{CO}_{2}$ by bio-oxidation (Mustin, 1987). The result shows a $\mathrm{C}$ : $\mathrm{N}$ ratio was increased in a final stage but it was reduced in control. The C:N ratio was used as an index for the maturity of organic matter. The final stage of vermicomposting the $\mathrm{C}: \mathrm{N}$ ratio was increased due to earthworm activities accelerate this dimension. The $\mathrm{C}: \mathrm{N}$ ratios were limited amount if it is too much level not favorable to earthworm development and could explain weak growth and reproduction in substrates with the high quality of water hyacinth (Gupta and Garg, 2003). So that the experiment was carried out 3:1 ratio (WH: $\mathrm{CW}$ ). Microflora namely bacteria, fungi, and actinomycetes were increased from initial to final stage because of the action of earthworms and also they contain essential nutrients to grow the microbes. Abundant enzyme activities in vermicompost than in normal compost lead to the decomposition process by the presence of earthworms and aerobic heterotrophic microbial population. Availability of half-digested nutrients rich organic waste by earthworm activity contributed for the proliferation of aerobic decomposing heterotrophic microorganisms. This finding was supported by Jambhekar (1992) reported that considerable increase in total viable counts of bacteria and fungi in the worm treated compost than the control.

Table.1 Physico-chemical analysis of vermicompost of water hyacinth with and without worm worked

\begin{tabular}{|c|l|c|c|c|c|}
\hline \multirow{2}{*}{$\begin{array}{c}\text { S. } \\
\text { No. }\end{array}$} & \multirow{2}{*}{ Characteristics } & \multicolumn{2}{|c|}{ Worm worked } & \multicolumn{2}{c|}{ Worm unworked } \\
\cline { 3 - 6 } & & $\begin{array}{l}\text { Initial } \\
\text { (0 days) }\end{array}$ & $\begin{array}{c}\text { Final } \\
\text { (45 days) }\end{array}$ & $\begin{array}{c}\text { Initial } \\
\text { (0 days) }\end{array}$ & $\begin{array}{c}\text { Final } \\
(\mathbf{4 5} \text { days })\end{array}$ \\
\hline 1. & $\mathrm{pH}$ & 08.54 & 7.49 & 10.0 & 8.34 \\
\hline 2. & $\mathrm{EC}$ & 03.80 & 4.5 & 4.1 & 4.2 \\
\hline 3. & $\mathrm{~N}$ & 01.77 & 2.85 & 1.22 & 1.51 \\
\hline 4. & $\mathrm{P}$ & 00.93 & 2.10 & 0.80 & 0.87 \\
\hline 5. & $\mathrm{~K}$ & 01.51 & 3.05 & 0.48 & 0.68 \\
\hline 6. & Organic Carbon & 67.30 & 62.85 & 22.21 & 20.05 \\
\hline 7. & C:N & 23.20 & 49.5 & 15.7 & 18.5 \\
\hline
\end{tabular}


Fig.1 The plant growth parameters were height, root length and number of leaves shoot and root biomass of Peanut in the presence of various concentration of enriched vermicompost of water hyacinth (Mean $\pm \mathrm{SD} ; \mathrm{n}=3$ )

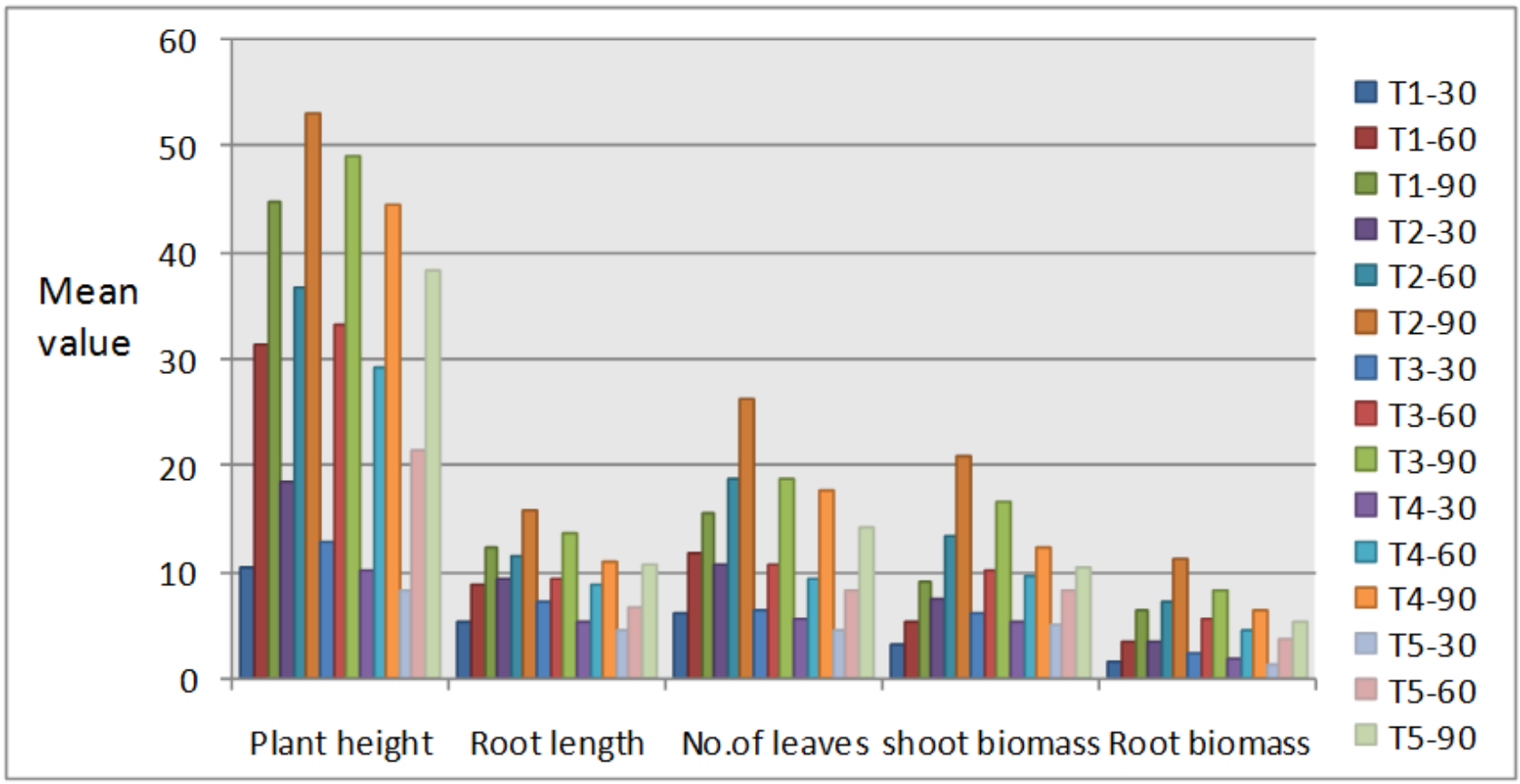

Fig.2 The Number of root nodules, number of individual fruit and weight of individual fruit of Peanut in the presence of various concentration of enriched -vermicompost of water hyacinth $($ Mean $\pm \mathrm{SD} ; \mathrm{n}=3$ )

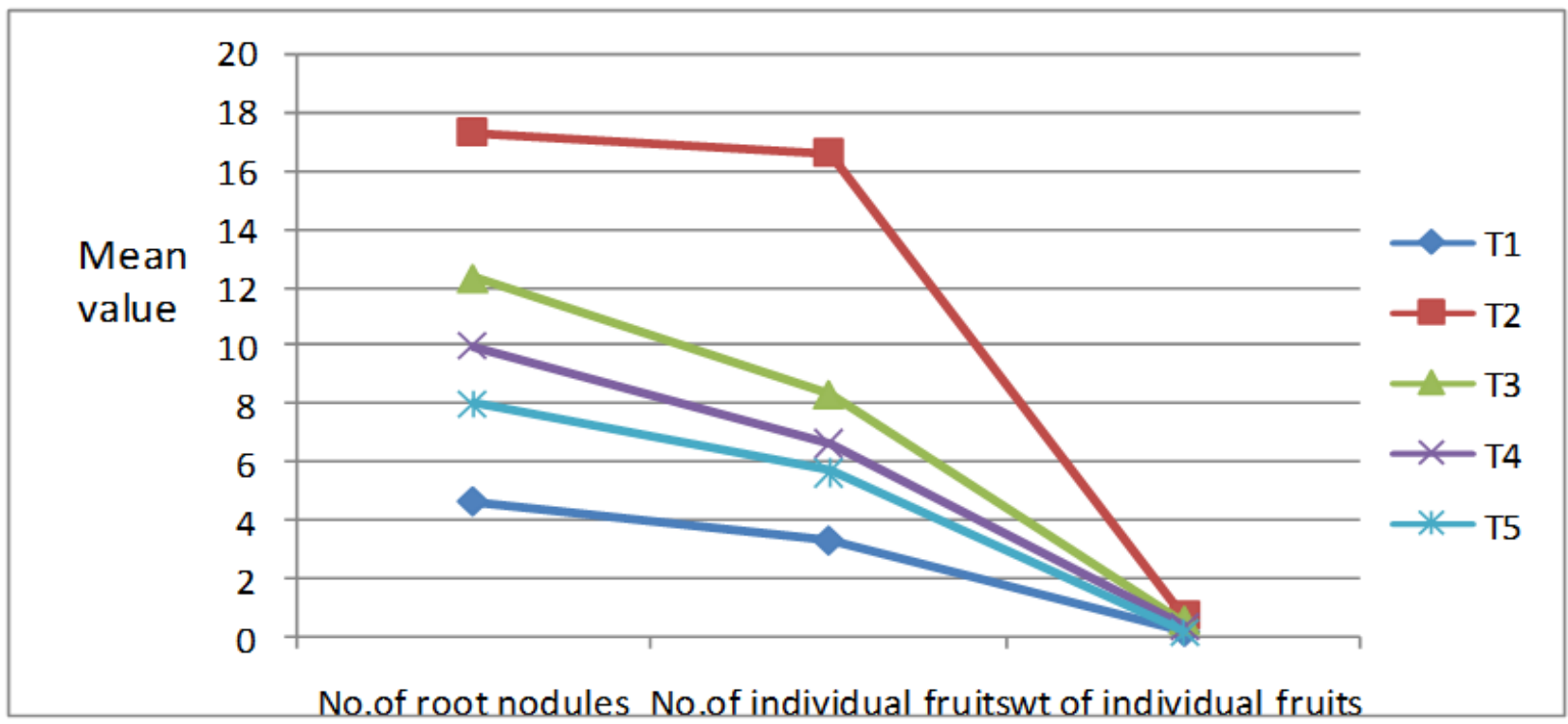

Germination percentage was observed in terms of normal seedlings was maximum (100 per cent) in $\mathrm{T}_{2}$ (soil+25 per cent
$\mathrm{VC}+\mathrm{MF})$. There was a gradual decrease in germination percentage in treatments $T_{3}$ (soil+35 per cent $\mathrm{VC}+\mathrm{MF}), \mathrm{T}_{4}($ soil +45 per 
cent $\mathrm{VC}+\mathrm{MF}$ ) and $\mathrm{T}_{5}$ (soil +35 per cent $\mathrm{VC}$ $+\mathrm{MF})$. The $\mathrm{T}_{4}$ and $\mathrm{T}_{5}$ show germination percentage of 70 per cent and 50 per cent respectively which were lower than the control $\mathrm{T}_{1}$ (Soil+WH) even where it was observed to be 30 per cent gradual decrease in germination indices in $\mathrm{T}_{4}$ and $\mathrm{T}_{5}$ can be attributed to the presence of nitrogen in excess.

Excessive nitrogen leads to inhibit seed germination. These findings were supported by Buckerfield et al. (1999), they reported that an increasing the concentration of vermicompost leads to decrease the germination of radish. The chlorophyll content was estimated and compared with control. The chlorophyll content was higher in $\mathrm{T}_{2}$ compared with other treatment over the control. Chlorophyll represents a principal class of pigments responsible for light absorption and photosynthesis was a complex process that was sensitive to environmental factors such as macro and micronutrients (Chaptin, 1980).

Plant growth and development was important for yield. In order to achieve sufficient amount of nutrients should be applied to the soil through inorganic and organic sources. Though the enriched vermicompost contains the higher percentage of plant nutrients were necessary for plant growth. The result shows higher plant growth and yield observed in $\mathrm{T}_{2}$ made up of 1:1 ratio (Soil: EVC) compared with other treatment and control $\left(\mathrm{T}_{1}\right)$ (Fig $\left.1 \& 2\right)$. The lowest plant growth was observed in $\mathrm{T}_{5}$ made up of 1:4 ratio due to the higher amount of enriched vermicompost that would affect the plant growth and yield. The result was supported by some other researcher, where they reported that the plant growth and development are affected by the rate of vermicompost applied to the soil which was in turns affected by agro- climatic conditions (Atiyeh et al., 2000).

In conclusion, the present study revealed that the supplementation of vermicompost would immediately benefit the farmers by increasing the yield of leguminous crop namely Peanut (Arachis hypogaea L.) and reducing the expenditure on inorganic fertilizers. Vermicompost can be used in place chemical fertilizer to increase the plant growth, crop yield and also improve the soil fertility. Further investigations in field application may be beneficial.

\section{References}

Abdelhamid, A.M. and Gaber, A.A. 1991. Evaluation of water hyacinth as feed for ruminants. Arch. Animal Nutri., 41(7/8): 745-756.

Ananthakrishnasamy, S., Manimegala, G., Sarojini, S., Gunasekaran, G. and Parthasarathi, K. 2007. Growth and reproduction of earthworm Eudrillus eugenia in bagasse: A sugar industrial waste. J. Appl. Zool. Res., 18(2): 149155.

Atiyeh, R.M., Arancon, N., Edwards, C.A. and Metzger, J.D. 2000. Influence of earthworm-processed pig manure on the growth and yield of greenhouse tomatoes. Biores Technol., 75: 175180.

Bhattacharya, S.S., and Chattopadhyay, G.N. 2004. Transformation of nitrogen during vermicomposting of fly ash. Waste Manage. Res., 22(6): $488-491$.

Buckerfield, J.C., Flavel, T.C., Lee, K.E. and Webster, K.A. 1999. Vermicompost in solid and liquid form as plant growth promoter. Pedobiologia, 43(6): 753-759.

Chapin, F.S. 1980. The mineral nutrition of wild plants. Annual Rev. Ecol. Systematics, 11: 233-260. 
Curry, J.P., Byrne, D. and Boyle, K.E. 1995. The earthworm population of a winter cereal field and its effect on soil and nitrogen turnover. Biol. Fertility of Soil, 19(2): 166-172.

Edwards, C.A. 1998. The use of earthworm in the breakdown and management of organic wastes. In: Edwards, C.A. (ed). Earthworm Ecology. CRC Press, Boca, Raton, FL. 327-354.

Gajalakshmi, S., Ramasamy, E.V. and Abbasi, S.A. 2001. The potential of two epigeic and two anecic earthworm species in vermicomposting of water hyacinth. Biores. Technol., 76(3): 177-181.

Ghosh, M., Chattopadhyay, G.N. and Baral, K. 1999. Transformation of phosphorus during vermicomposting. Biores. Technol., 69(2): 149-154.

Gupta, R. and Garg, V.K. 2003. Stabilization of primary sewage sludge during vermicomposting. $J$. Hazardous Materials, 153(3): 10231030.

Huang, G.F. 2004. Effect of $\mathrm{C} / \mathrm{N}$ on composting of pig manure with sawdust. Waste Manage, 24(8): 805 813.

Jambhekar, H. 1992. Uses of earthworm as a potential source of decomposing organic waste. In: Proceedings of the National Seminar on Organic Farming, Coimbatore. $52-53$.

Kale, R.D. 1998. Earthworm: Cinderella of Organic Farming. Prism Publisher, Bangalore, India. 1-88.

Mustin, M. 1987. Le compost - gestion de la matière organique. Editions François Dubusc-Paris. 1-954.

Sanchez-Monedero, M.A., Roig, A., Paredes, C. and Bernal, M.P. 2001. Nitrogen transformation during organic wastes composting by the Rutgers system and its effects on $\mathrm{pH}$, EC and maturity of the composting mixtures. Biores. Technol., 78(3): 301-308.

Suthar, S. 2007. Vermicomposting potential of Perionyx sansibaricus (Perrier) in the different waste material. Biores. Technol., 98(6): 1231-1237.

\section{How to cite this article:}

Sridevi, S., M. Prabu and Tamilselvi, N.G. 2016. Bioconversion of Water Hyacinth into Enriched Vermicompost and its Effect on Growth and Yield of Peanut. Int.J.Curr.Microbiol.App.Sci. 5(9): xx-Xx. doi: http://dx.doi.org/10.20546/ijcmas.2016.509.078 